\title{
Mednarodna izhodišča in prostorski razvoj Slovenije
}

\author{
(Urbani izziv, letnik 11, št. 1: Urbana omrežja)
}

\section{Uvod}

Članek povzema nekatere bistvene teze raziskovalne naloge Mednarodna izhodišča in prostorski razvoj Slovenije, ki so jo avtorji (nosilec prof. dr. Pogačnik, soavtorja prof. mag. Gabrijelčič in viš. pred. mag. Zavodnik) z Univerze $\mathrm{v}$ Ljubljani izdelali za Ministrstvo za okolje in prostor v okviru priprav na prostorski plan Slovenije.

Ob tem izpuščamo opise analitičnih gradiv, še zlasti splošno znane opredelitve iz temeljnih dokumentov, kot so Agenda 2000, Evropa 2000+, ESDP, dokumenti CEMAT, CADSCEC itd. Še toliko bolj, ker so ta načela pisana $v$ jeziku, ki daje prav vsem pozitivnim smerem razvoja, težava pa se pojavi pri aplikaciji v realni prostor. Izkaže se, da so mnoga načela ob hkratnem upoštevanju - kontradiktorna in je potrebno izbrati eno od možnosti. V tem članku podajamo samo tiste predloge prostorskega razvoja Slovenije, ki so korak dlje od kar številnih domačih študij na temo vključevanja v prostor Evropske unije. Ti pogledi že sedaj vzpodbujajo različne kritične odmeve, ker se odmikajo od inercijskega ponavljanja stališč v naši stroki. V članku izpuščamo pasuse o demografiji, sociali, gospodarstvu, ukrepih za implementacijo - saj so (kljub temu, da imamo prostorci tudi tu lastna videnja) za to bolj merodajne druge raziskave oziroma izvajalci prostorskega plana države.

Ker je urejanje prostora $\mathrm{v}$ domeni posameznih držav članic EU in ne skupne evropske zakonodaje, je smiselno, da bomo $\mathrm{v}$ Sloveniji sprejeli in koristno uporabili vse tiste mednarodne usmeritve, ki so v našo korist, zadržani pa bomo pri tistih, ki nam škodujejo, oziroma bomo pri njih izvajali svojo lastno prostorsko politiko.

\section{Regionalizacija in čezmejno sodelovanje}

Slovenija mora izkoristiti svojo pripadnost oziroma prisotnost $\mathrm{v}$ alpskih, mediteranskih, srednjeevropskih in podonavskih regionalizacijah, saj je na območju prekrivanja teh regij, čeprav ne leži v njihovih osrednjih, razvojno najbolj perspektivnih prostorih. Leži ugodno tudi glede na širitev EU proti vzhodu v smeri višegrajskih, črnomorskih in balkanskih držav. Čeprav ni znotraj regij teh držav, pa je na odlični strateški legi povezav zahodne in srednje Evrope ter Sredozemlja $z$ naštetimi regijami.

Ob tem ne smemo prezreti dejstva, da bodo $v$ prihodnosti tudi vzhodno od nas (in ne samo zahodno) vznikale gospodarsko osrednje regije ter urbano zgostitvene regije in urbane osi, ki bi nas lahko puščale ob strani:

- Os podonavskih držav s podaljškom do Berlina, prek Prage, Dunaja in Budimpešte do Beograda, Bukarešte in Črnega morja.

- Trikotnik Dunaj - Praga - Bratislava - Budimpešta bo nova vozliščna urbana regija.

- Velika razvojna in urbanizacijska os se bo razvila med Zagrebom, Beogradom, Sofijo in Istanbulom.

- Povezava Švedske z Dansko in Nemčijo (oziroma Skandinavije z zahodno Evropo) bo okrepila os sever - jug in s tem osrednje razvojne prostore Evrope ter povzročila premikanje "banane" proti vzhodu, zlasti severno od nas.
Evropska unija Policentrizem Prostorski razvoj Regionalizacija Slovenija

Članek podaja glavne usmeritve $i z$ istoimenske raziskovalne naloge, ki jo je avtor obdelal skupaj s soavtorjema prof. Petrom Gabrijelčičem in viš. pred. Almo Zavodnik. Prikazane so use prednosti in nevarnosti, ki jih za slovenski prostor predstavlja vključitev $v$ Evropsko unijo. Splošna načela, najbolj izrazito izražena $v$ dokumentu ESDP, so za Slovenijo sprejemljiva s tem, da je potrebno bolj poudariti mrežo mest, sistem varovanih naravnih območij, konkurenčnost nasproti bližnjim tujim urbanim središčem, pritegniti transportne tokove, iskati tržne niše $v$ kmetijstvu in proizvodnji ter ohranjati identiteto slovenskih mest in krajin.

\section{European Union Poly-centrism Regionalism Slovenia Spatial development}

The author presents the key findings from a research project with the same title he conducted, together with prof. Peter Gabrijelčič and senior lecturer Alma Zavodnik. The spatial aspects of advantages and dangers for Slovenia following acssesion to the European Union are shown. The general principles as pointed out in the document ES$D P$ are acceptable for Slovenia, as long as the urban network and system of protected natural areas are better emphasised, coupled with competitiveness with neighbouring foreign urban centres, attracting transport flows, searching for market niches in agriculture and production and maintaining the identity of Slovenian cities and landscapes. 
letnik 11, št. 2/00

Smiselno je, da s sosednjimi državami oblikujemo čezmejne regije zlasti na hribovitih, teže dostopnih območjih s številnimi problemi gospodarskega in demografskega nazadovanja (na obeh straneh državne meje), tako da bodo na ta način formirane regije oblikovale skupne razvojne programe za pomoč strukturnih skladov EU. V taki regionalizaciji mora biti Slovenija enakovreden partner.

Oblikovanje regij $z$ deli sosednjih držav naj bo usmerjeno tudi v pritegnitev slovenskih manjšin, tj. v reintegracijo slovenskega etničnega ozemlja, kar ima za nas tudi gospodarski, kulturni, zgodovinski in politični pomen. Predlagane čezmejne regije so:

- "Troregija" - regija treh držav: Slovenije, Italije in Avstrije (Benečija, Kanalska dolina, Ziljska dolina, jugozahodna avstrijska Koroška, v Sloveniji pa TNP, zgornje Posočje, gornja Gorenjska, Karavanke do vključno Jesenic). Glavno urbano središče na slovenski strani so Jesenice (in sekundarno Tolmin).

- "Kvatroregijau - regija štirih držav: Slovenije, Avstrije, Madžarske in Hrvaške (južna Gra- diščanska, Porabje, Medjimurje, v Sloveniji pa Goričko, Prekmurje in Prlekija). Glavno urbano središče te regije na slovenskem ozemlju je Murska Sobota.

- "Slovensko-hrvaška regija Obkolpje" (notranjsko-snežniško območje, Kočevsko, Obkolpje, Gorski Kotar, Risnjak), s Kočevjem kot slovenskim urbanim težiščem.

Druge čezmejne regije oziroma evro mikroregije niso problemske, temveč zgostitvene in prosperitetne. Formirale se bodo spontano zaradi naglega razvoja urbanizacije, prometa, turizma, trgovine, proizvodnje ipd. Med njimi je najizrazitejša "evroregija", ki jo sestavljajo Trst, slovenska Obala, hrvaška Istra. Nevarnost je velika gravitacijska moč Trsta (skupaj z Ronkami, Miljami, Tržičem ...), ki bi vso okolico vključno $z$ Istro lahko spremenili v "zaledje" velikega Trsta oziroma vplivno območje dveh težišč (pri čemer je drugo Reka), zaradi česar bi bil slovenski prostor lahko marginaliziran, izrazito obroben in prehoden. Mnenja smo, da edino izrazito razvojna naravnanost na sloven-

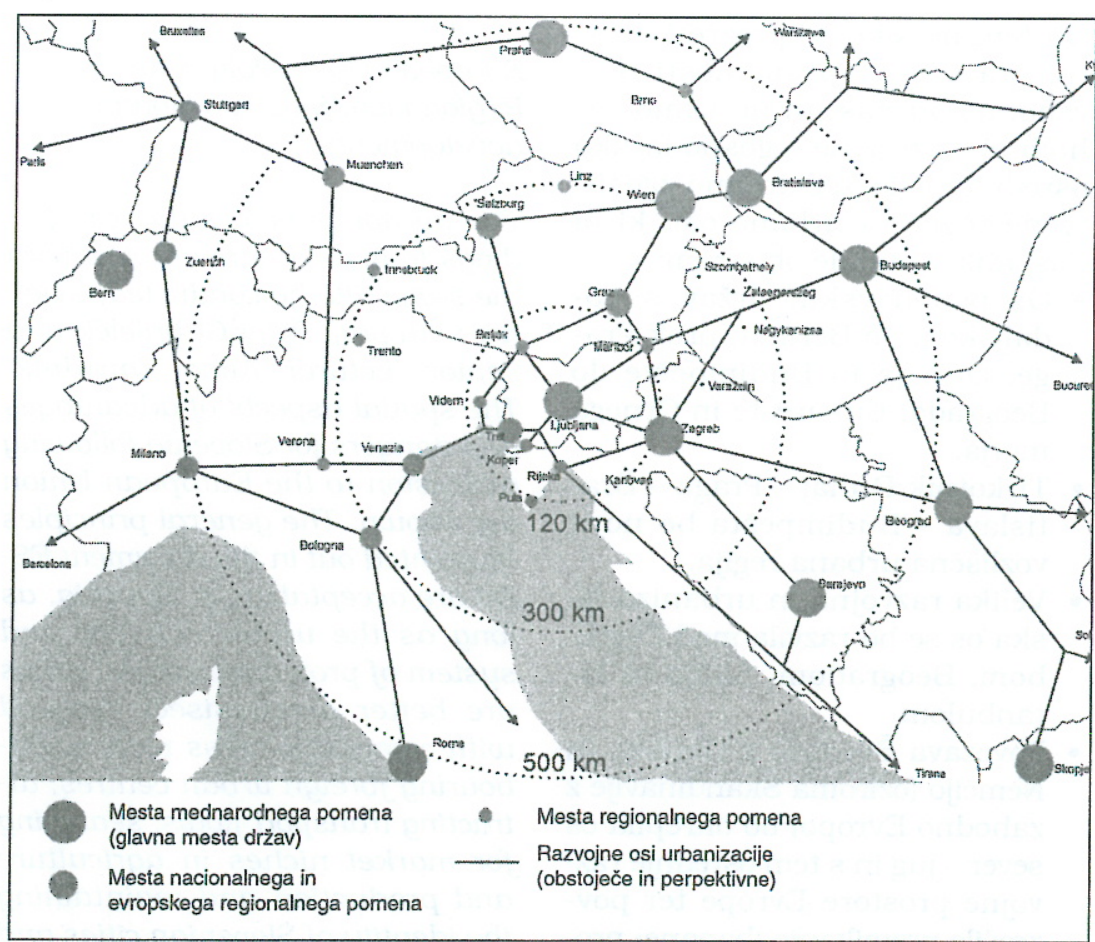

Slika 1: Vključevanje Slovenije v evropsko urbano omrežje ski Obali in njenem zaledju, na tržaško-komenskem krasu lahko uravnovesi opisane pretnje in je za nas pozitivna. Tudi širjenje mediteranske evroregije proti severu $z$ vključitvijo Gorice in Nove Gorice je za nas zelo vprašljivo zaradi perifernosti naših ozemelj in šibke konkurenčnosti glede na Furlanijo, mesto Gorico oziroma konurbacijo Videm - Gorica.

Druga, podobno vprašljiva tendenca je "evroregija Graz - Maribor", v kateri bi Maribor potegnil krajši konec. Maribor je nesporno urbano središče vzhodne Slovenije, s pomembno vlogo sekundarnega nacionalnega središča ter oskrbe občinskega zaledja. Ima vse možnosti (prometne, gospodarske, izobraževalne, kulturne, turistične ...), da postane evropsko regionalno urbano središče. Njegova "masa" je zadostna, da na našem ozemlju povsem uravnoteži vpliv Gradca oziroma avstrijske Štajerske, ki mu je konkurenčna. $\mathrm{V}$ morebitni "delitvi funkcij" $\mathrm{Z}$ Gradcem bi Maribor igral podrejeno vlogo, kar velja tudi za sicer v Mariboru ugodne lokacije (prometno vozlišče, letališče, gospodarske cone, univerza itd.).

\section{Policentrizem, urbane mreže in koridorji}

Strokovno ustrezno in družbeno sprejeto policentrično zasnovo urbanizacije Slovenije je potrebno sicer nadgraditi $v$ skladu $\mathrm{z}$ najnovejšimi spoznanji in izzivi glede metropolizacije, mreženja in koridorskega razvoja v urbanih oseh. Na ta način bomo skušali rešiti oba problema - urbano oskrbo perifernih regij in hkrati doseči razvito evropsko konkurenčno mrežo mest z izpostavitvijo vloge državnega glavnega mesta (Ljubljane), evropsko regionalno pomembnega mesta (Maribora) in (edinega) evropskega vhodnega mesta (Kopra).

Poleg osnovne usmeritve, tj. policentrične zasnove urbanizacije, je mesta, kot rečeno, potrebno povezovati v mreže in razvojne koridorje - oboje zaradi večje konkurenčnosti sicer (pre)majhnih sloven- 
skih mest in njihovega vključevanja v urbani sistem Evrope. Predlagamo sledeči "urbani sistem".

Glavno mesto Ljubljano je potrebno poudarjeno razvijati kot "Evrocity", saj je edino slovensko srednje veliko evropsko mesto, ki je hkrati metropola in središče mreže urbanih aglomeracij v okolici ki so: Kranj, Škofja Loka, Kamnik, Domžale, Litija, Grosuplje, Vrhnika, Logatec (in manjša obmestna urbana naselja, kot so Horjul, Ig, Polhov Gradec, Medvode, Vodice, Mengeš, Trzin, Škofljica, Brezovica in druga).

Maribor je potrebno razvijati kot regionalno pomembnejše srednjeevropsko mesto in hkrati kot središče urbane mreže $z$ okolnimi urbanimi aglomeracijami, ki so: Ptuj, Slovenska Bistrica, Ruše, Limbuš, Bresternica, Rače, Fram, Pesnica in druga.

Koper je nujno potrebno vsestransko razvijati kot (naše edino) vhodno mesto (gate way city) Evrope. Skupaj z njim tvorijo tretjo urbano mrežo obalna mesta, in sicer: Izola, Piran, Portorož, Lucija, skupaj z manjšimi aglomeracijami (kot so Dekani, Sečovlje, Škofije, Korte, Šmarje, Ankaran in druge).

Druge mreže mest in urbanih središč, ki krepijo urbana središča slovenskih regij ali tvorijo konkurenčno težišče velikim mestom na drugi strani meje, sestavljajo sledeča mesta:

- Jesenice, Radovljica/Lesce, Bled;

- Sežana, Kozina, Divača;

- Zagorje, Trbovlje, Hrastnik;

- Dravograd, Slovenj Gradec, Ravne na Koroškem;

- Brežice, Krško;

- Nova Gorica, Šempeter, Solkan, Volčja Draga, Vrtojba;

- Celje, Žalec, Polzela, Trnovlje;

- Velenje (Škale, Pesje), Šoštanj, Topolščica.

Regionalni urbani centri, ki so $\mathrm{v}$ okviru policentrične zasnove poleg naštetih urbanih mrež središča $z$ višjo ravnjo oskrbe, sta Novo mesto in Murska Sobota ter pomožna regionalna središča: Po- stojna, Kočevje, Idrija, Tolmin, Ilirska Bistrica.

Druga manjša urbana središča so nosilci razvoja posameznih mikroregij in hkrati pomembni oskrbovalni centri za podeželsko okolico. Evropske usmeritve ne govorijo o "najmanjših možnih" urbanih središčih v policentričnem razvoju. Zato bodo določeno (nižjo in delno srednjo) raven funkcij razvijala vsa ostala mesta, zlasti tista, ki so bila nekclanja središča občin (npr. Črnomelj, Ormož, Lendava, Slovenske Konjice, Rogaška Slatina, Trebnje, Ajdovščina, Bovec, Kobarid, Ribnica, Radeče ...), pa tudi vsa središča novih občin, vsaj za osnovno raven funkcij.

Glede na odprtost naših meja po vključitvi v EU bosta narasla pomen (nacionalni, identitetni) in hkrati konkurenca našim obmejnim mestom. Zato je v njih treba razvijati nacionalno pomembne funkcije (npr. izobraževalne, kulturne, upravne, denarne), tudi če so pod pragom ev. demografske ali gospodarske upravičenosti. Takšna mesta so: Gornja Radgona,
Murska Sobota, Lendava, Ormož, Rogaška Slatina, Brežice/Čatež, Metlika, Koper (že opredeljen kot vhodno mesto), Sežana, Nova Gorica, Ilirska Bistrica, Kranjska Gora; na lokalni ravni pa še manjša urbana središča, kot so Vinica, Fara, Jelšane, Miren, Kobarid, Dravograd, Šentilj, Hodoš, Središče ob Dravi, Rogatec, Bistrica ob Sotli, Osilnica in druga.

\section{Terciarne in kvartarne dejavnosti}

Glede na razporeditve centralnih funkcij $\mathrm{v}$ mestih ali specializiranih centrih nam mednarodna izhodišča ne dajejo neposrednih usmeritev. Zaradi trendov razvoja, konkurence sosednjih (čezmejnih) mest in ob opazovanju stanja v najrazvitejših državah Evrope in sveta pa lahko kot mednarodne usmeritve postavimo sledeče teze.

Globalizacija, spremembe $\mathrm{v}$ hierarhiji funkcij in drugi trendi $\mathrm{v}$ svetu terjajo vse večjo koncentracijo, obseg, specializacijo in

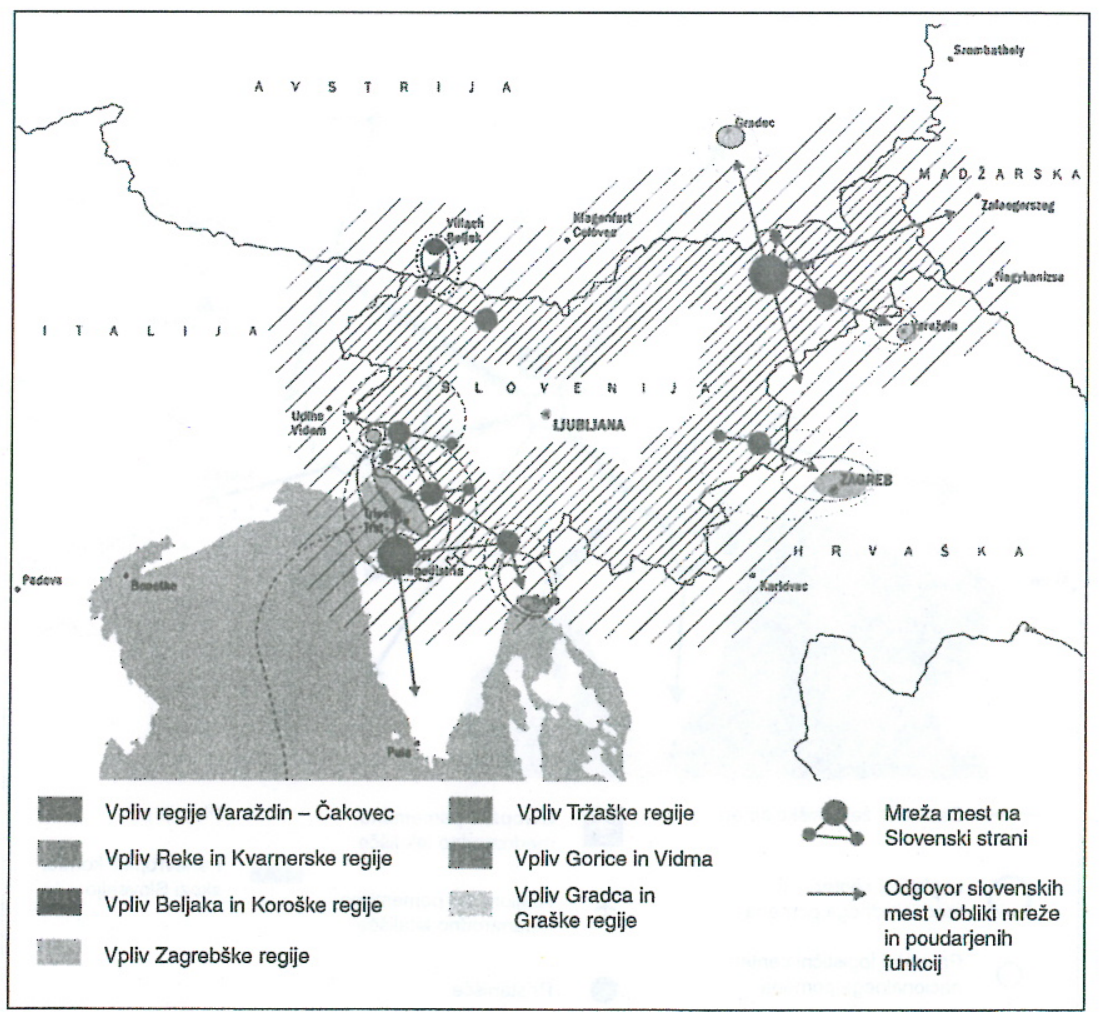

Stika 2: Gravitacijski vpliv velikih sosednjih mest in aktivni scenarij na teh območjih 
raznovrstnost centralnih funkcij $\mathrm{v}$ velikih mestih in specializiranih središčih (npr. visokega šolstva, zdraustva, bančništva, trgovine, kulturne in turistične ponudbe, športa, prometnih storitev, pojavnosti ...). Posebej pomembno vlogo ima v tem pogledu Ljubljavisoko kakovostjo terciarnih in kvartarnih dejavnosti izboriti razpoznavno mesto $\mathrm{v}$ konkurenci evropskih metropol. Podobno velja za Maribor, ki naj na ta način postane pomembno mesto $\mathrm{v}$ okviru srednje Evrope.

Zlasti bo pomembna mreža visokih šol, univerz in znanstveno-tehnoloških parkov (v Ljubljani, Mariboru, na Obali, v Novi Gorici, Novem mestu ...).

Centralne funkcije na srednjih in nižjih ravneh bomo umeščali $\mathrm{v}$ prostor policentrično oziroma $\mathrm{v}$ prometno najbolj dostopna mesta ter s tem oskrbovali čim bolj enakomerno vse regije, še zlasti pa teže dostopne in gospodarsko zaostale predele. sloune, kongresne, sejemske dena, ki si mora s koncentracijo in

Naši interesi ohranjanja nacionalne identitete na obmejnih območjih, ki so v vplivu velikih sosednjih mest, narekujejo čim večjo koncentracijo centralnih funkcij tudi v Novi Gorici, Sežani, Kopru (Izoli), Ilirski Bistrici, Brežicah, Gornji Radgoni, Slovenj Gradcu, Črnomlju, Ormožu, Lendavi (trgovine, šolstua, zdravstva, turizma in prostočasnih dejaunosti, kulturnih dejavnosti, denarnih ustanov ipd.).

Slovenija lahko nudi ugodne lokacije za proizvodna podjetja in špedicijske centre multinacionalnih družb, ki lahko "pokrivajo" več sosednjih nacionalnih tržišč (Italije, Avstrije, Madžarske, Hrvaške ter deloma tudi $\mathrm{BiH}$ in Jugoslavije). Takšni logistični centri so zlasti Ljubljana (katere prednost je tudi lega v središču domače potrošnje), Maribor in Koper, potencialno pa tudi Sežana, Kozina, Brežice, Celje in drugi.

Za velika nakupovalna središča in druge komercialne dejavnosti nadnacionalnega pomena naj bodo predvidene nekatere prometno izjemne lokacije (npr. zaledje Luke

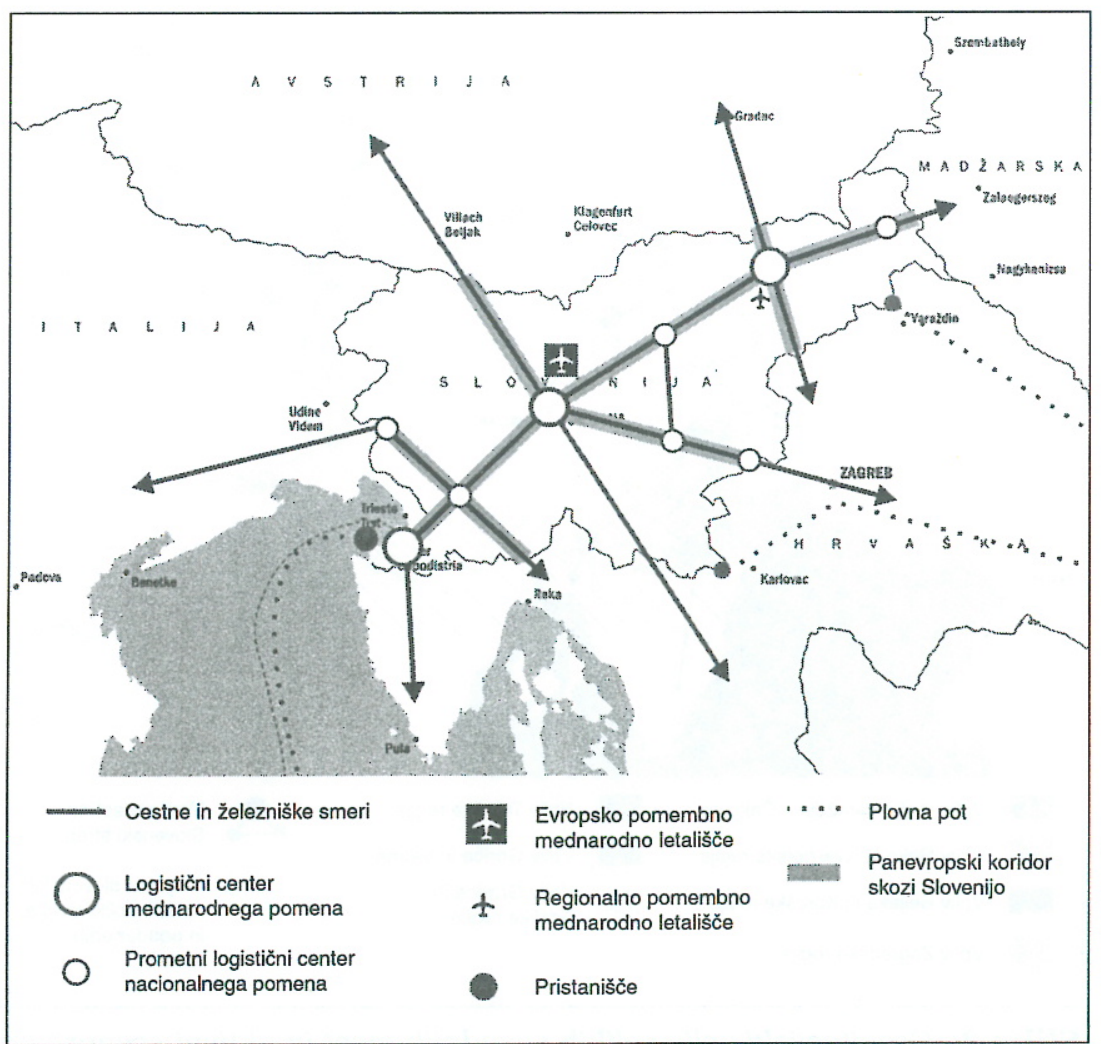

Slika 3: Aktiuni scenarij za preprečitev prometne izolacije
Koper, Kozina, Vrtojba/Nova Gorica, Brežice - Čatež, Jelšane, Macelj, Jesenice, Gornja Radgona, Dravograd, Lendava in druge).

Tudi zdravstvo in skrb za ostarele (penzioni, sanatoriji, naselja zaprtega tipa) lahko pokrivajo potrebe delov populacije iz bližnjega zamejstva, kar velja za tiste lokacije, ki ležijo ali v središču ali v bližini velikega populacijskega zaledja (npr. v Izoli, Sežani, Šempetru pri Novi Gorici, Brežicah - Čatežu, Rakičanu, Radencih, Rogaški Slatini, na Golniku ...) ali pa kot koncentracija $z$ vrhunskimi storitvami $\mathrm{v}$ državni metropoli (UKL). Druga zdravstvena središča imajo zlasti regijski pomen (npr. Maribor, Novo Mesto, Celje, Slovenj Gradec, Kranj, Jesenice ...) oziroma so izrazito specializirana v okviru domačih potreb.

Umetni (grajeni) rekreacijski ali športni objekti in naprave (najvišje hierarhične stopnje ali specialnosti funkcij) naj s svojimi lokacijami zaradi majhnega (notranjega) tržišča oziroma klientele podpirajo zlasti turistični razvoj krajev (npr. Bled, Portorož, Bovec, Zreče, Kamnik, Slovenj Gradec, Čatež, Podčetrtek, Gornja Radgona, Maribor, Ptuj ...). Ljubljana tudi zaradi mednarodnih potreb nujno potrebuje osrednji atletski (in nogometni) stadion ter osrednjo športno dvorano. Smotrno bi bilo razviti nekatere evropsko razpoznavne športne in zabaviščne cone, zlasti ob velikih sečiščih prometnic in bližini zaledja več držav (npr. avtodrom, vodni ali zabaviščni park pri Divači ali Kozini, Mariboru, Ptuju).

\section{Industrija, gradbeništvo in malo gospodarstvo}

Za evropsko in svetovno konkurenčnost izvozno usmerjene proizvodnje je potrebno nuditi ustrezne prostorske možnosti, torej prostorske lokacije industrijskih in obrtnih con, s čim boljšo prometno, energetsko in okoljevarstveno 
infrastrukturo. Kot podpora človeškim proizvodnim potencialom pa so pomembni kakovostni sistemi šolstva, zdravstva, stanovanjsko okolje (zaposlenih), možnosti za kulturno udejstvovanje, rekreacijo, šport in druge prostočasne aktivnosti.

Konkurenčna, visoko tehnološko razvita industrija je ena trajnih usmeritev EU in hkrati splošen trend v razvitem svetu. Slovenska industrija naj bo trajnostna, torej naj čim manj obremenjuje okolje, naj bo čim manj energetsko potratna, ima naj urejeno ravnanje $z$ odpadki, čim bolj vzdržno naj koristi naravne vire. Temelji naj na znanju in kakovostnih človeških potencialih. Poleg velikih industrijskih podjetij so za Slovenijo zlasti pomembni mala podjetja, proizvodna obrt in tudi delo na domu.

Vključevanje v globalna gospodarska gibanja za Slovenijo pomeni nujnost odpiranja velikih gospodarskih con za pritegnitev tujih in domačih investitorjev, skratka za vključevanje v mednarodne tokove industrijske proizvodnje, prometa, servisov, distribucijskih centrov velikih (multinacionalnih) družb itd.

Najmanj, kar lahko in kar moramo storiti, je, da nudimo kar najbolj tekmovalne pogoje tujim (in domačim) investitorjem, ki bodo enaki ali boljši kot v tujini: zlasti na križiščih in vozliščih E-5 in E10 evro-koridorjev.

Prostorsko moramo opredeliti ter razvijati sledeče gospodarske cone, ki so nadnacionalnega, useevropskega pomena in ki so (edine) lahko mednarodno konkurenčne zaradi svoje prometne dostopnosti, infrastrukturne opremljenosti, zaledja, znanja in kakovostne delovne sile. Te so:

- Ljubljana: ITSC Moste-Zalog in Ljubljana-Brnik;

- Koper: na območju luke in v njenem zaledju;

- Maribor: cona ob križišču avtocest, železnici in letališču;

- Divača: cona ob avtocestnem križišču in železnici;

- Brežice: Bregana.
Gospodarske cone regionalnega in čezmejnega (s sosednjimi državami) pomena bomo poudarjeno razvijali v večjih mestih zlasti ob meji in na območjih stare industrije, ki terja nujno prestrukturiranje (tudi v obliki malih podjetij oziroma proizvodne obrti), in sicer zlasti $\mathrm{v}$ sledečih mestih: Jesenice, Trbovlje, Celje, Novo mesto, Kranj, Velenje, Sežana, Kočevje, Idrija, Ravne na Koroškem, Ilirska Bistrica, Nova Gorica/Šempeter/Vrtojba, Murska Sobota, Lendava.

Tehnološke razvojne parke (visokih tehnologij) bomo razvijali v mestih $z$ univerzitetnimi in raziskovalnimi institucijami, zlasti pa v Ljubljani, Mariboru, Kopru (v okolici, zunaj območja luke), Novi Gorici, Novem mestu, Celju in Kranju.

\section{Kmetijstvo in gozdarstvo}

Mednarodne usmeritve poudarjajo vlogo konkurenčnega, intenzivnega in specializiranega kmetijstva na območjih, kjer so za proizvodnjo hrane najbolj ugodni naravni pogoji. EU si s tem želi izbo- riti svoj delež na svetovnem trgu kmetijskih proizvodov, zmanjšati odvisnost od uvoza in komparativno izkoristiti lastne potenciale. $\mathrm{Ob}$ tem seveda poudarja načela trajnostnega razvoja, varovanje krajine, upoštevanje okoljskih omejitev, zlasti glede kemizacije tal in zaščite virov pitne vode.

Zato bi bilo nesmotrno prostorsko destimulirati intenzivno kmetijsko proizvodnjo v Sloveniji na tistih območjih, ki imajo vsestransko ugodne pogoje, konkurenčne in primerljive s tistimi v EU in drugod po svetu. Zaradi razdrobljenosti in majhnosti obsega kmetijskih zemljišč morajo prebivalci teh območij iskati specializirane tržne niše in dodaten zaslužek v nekmetijstvu. Kjer so pogoji za večje zložbe, arondacije, nakupe sosednjih parcel in nastajanje velikih posesti, naj za to ne bo omejitev.

Takšna mednarodna usmeritev nas vodi $\mathrm{k}$ določitvi območij prednostnega razvoja kmetijstva, ki naj bodo Pomurje, Slovenske gorice, Apaško polje, Dravsko-ptujsko polje, ravninski svet na območjih Dolenjske (Krško polje), Savinjska kotlina, Radovljiško, Kranjsko in

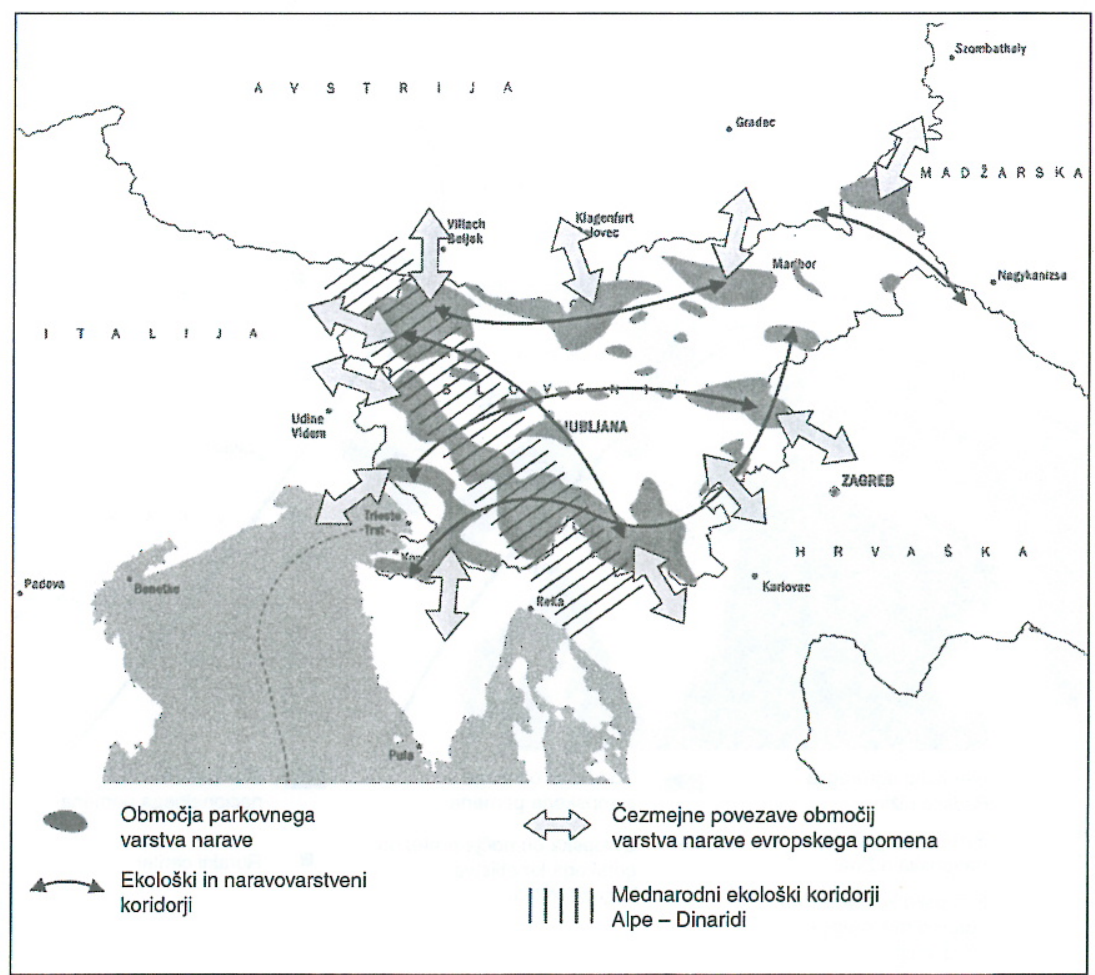

Slika 4: Sistem varstua narave 
Domžalsko-kamniško polje, spodnja Vipavska dolina in Vrtojbansko polje, Goriška brda, podolja v zaledju Koprščine. $\mathrm{Na}$ naštetih prednostnih območjih za razvoj kmetijstva naj bi bile možne večje agromelioracije, namakanje, oblikovanje velikih posestev (farm), gradnja steklenjakov, lokacija agroživilske industrije.

Zaradi izjemno nizke cene kmetijskih zemljišč (v Sloveniji) je potrebno na teh območjih omejevati nakupovanja nekmetov in tujcev (omejitev velikosti največje posamične farme ali deleža tujih lastnikov v naselju ...). V obratnem primeru obstaja nevarnost nastajanja veleposestev $\mathrm{v}$ rokah tujcev in s tem trajne izgube dela našega narodnega bogastva.

Urbano oskrbo opisanih agroregij naj zagotovijo ruralni centri, ki naj razvijajo poleg drugih urbanih funkcij tudi agroživilstvo, šolstvo za kmetijske dejavnosti, kmetijske inštitute in pospeševalne službe.

V drugih predelih Slovenije, kjer so slabši pridelovalni pogoji, niso pa v območjih parkovnega varstva narave, naj se razvija trajnostno kmetijstvo hkrati $z$ dopolnilnimi dejaunostmi predelave kmetijskih izdelkov, gozdarstva, podjetništva in urbanizacije (kot so npr. ostala agrarna območja Dolenjske, Zasavja, obrobje Celjske kotline, Škofjeloško-Cerkljansko, srednje Posočje, Bela krajina, Haloze, kotline in doline slovenske Koroške in Štajerske, nezaščitena območja kraških polj ter podolij itd.). V naštetih območjih je možna tudi intenzifikacija in specializacija $\mathrm{V}$ tržno zanimive proizvode (proizvodne niše), kot so pridelava $\mathrm{v}$ rastlinjakih, ovčereja, perutninarstvo, sadjarstvo, vinogradništvo, jagodičarstvo ...

$\mathrm{V}$ območjih varstva narave, tj. v krajinskih, regijskih in spominskih parkih, naj ima kmetijstvo zlasti funkcijo vzdrževanja in nege kulturne krajine. Podrejeno naj bo krajinski tipiki, okoljski nosilnosti, varovanju drobnih struktur in biotopov ter vsem drugim paradigmam trajnostnega razvoja. Poleg okolju prijaznega kmetijstva naj bodo tu možnosti dodatnih zaposlitev $\mathrm{v}$ turizmu, obrti, gozdarstvu. Intenzifikacija

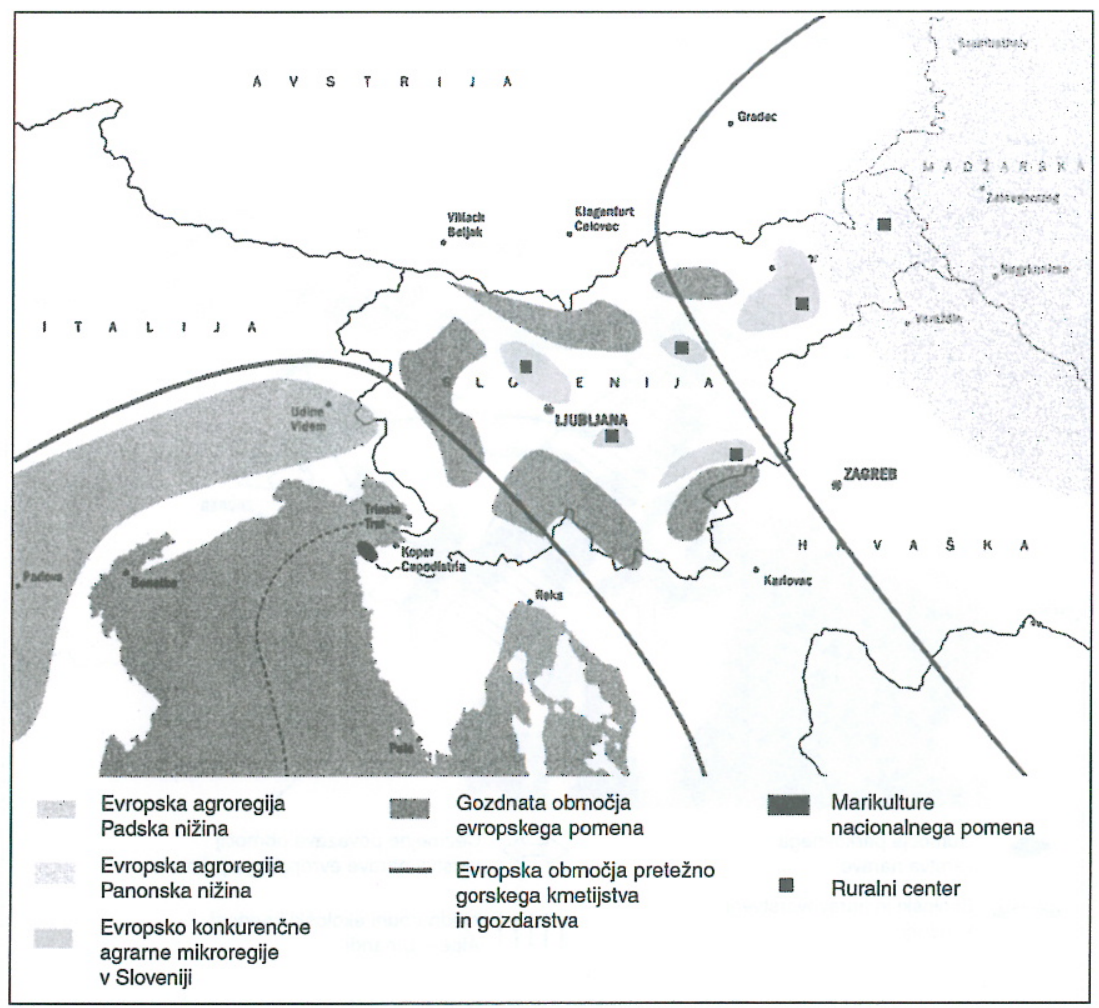

Slika 5: Vloga kmetijstva in gozdarstva glede na sosednje regije naj bi bila možna le v planinskem svetu v smeri živinoreje. Plantažni nasadi, steklenjaki ali večji agrotehnični posegi naj bi bili destimulirani. Na izbranih lokacijah bi bila možna gradnja vikendov, $v$ ta namen naj bi bila podpirana prenova starih etnografsko vrednih zgradb. V opisanih območjih je nujno oblikovati take razvojne programe, da bodo lahko sofinancirani od strukturnih skladov EU - kot so izboljšanje prometne dostopnosti, razvoj turizma, dela na domu, okoljska sanacija, varstvo narave, prenova ipd. Značilna območja takih usmeritev kmetijstva so Goričko, Pohorje, Kozjansko, Gorjanci, dolina Krke, Karavanke in Savinjske Alpe, Banjščica in Trnovski gozd, Tržaško-komenski kras, Brkini, območja na Notranjskem, ki so v krajinski zaščiti, Obkolpje, JZ deli Kočevskega, Polhograjski Dolomiti, Ljubljansko barje, Menina, Julijske Alpe zunaj Triglavskega narodnega parka itd.

V zadnji skupini so tista kmetijska območja, ki ležijo v narodnem parku in drugih območjih najvišjih vrednot krajine in naravne dediščine. Tu naj bi bile omejitve še večje, tudi v smislu varstva arhitekturne dediščine, parcelacije, drobnih struktur, vendar ob možnih dodatnih zaposlitvah $\mathrm{v}$ kmečkem turizmu, domači obrti, gozdarstvu. Naselja novih vikendov naj bi bila omejena ali celo prepovedana, razen prenove starih zgradb v tak namen.

Evropski oziroma mednarodni pomen gozdov je zlasti njihova okoljevarstvena funkcija. Mednarodne usmeritve poudarjajo njihovo habitatsko vlogo, vlogo kot sestavino naravnih krajin, pa tudi gospodarske funkcije. Zato je velika gozdnatost Slovenije za nas v načelu pozitivna. Negativno (tudi glede na mednarodne usmeritve) pa je širjenje gozdov na račun kmetijskih zemljišč. Gozd mora poleg vsestranske okoljske funkcije hkrati služiti tudi kot dopolnilna dejavnost v kmetijstvu, za potrebe turizma in rekreacije $\mathrm{v}$ naravi. Kot habitate oziroma ekološke niše je potrebno varovati tu- 
di manjše gozdne sestoje (npr. v ravninah), zlasti na območjih ekoloških koridorjev, ki naj povezujejo "otoke" pretežno ohranjenega naravnega okolja.

Glede na mednarodne primerjalne prednosti so v Sloveniji nekatera območja strnjenih gozdov najvišje proizvodne vrednosti, ki predstavljajo potencial za gospodarski razvoj na osnovi lesnopredelovalne industrije, gozdnih plodov, energetske samooskrbe $z$ izkoriščanjem lesne biomase itd. Zato moramo hkrati $z$ varovalno razvijati tudi proizvodno funkcijo in smotrno izkoriščati gozdno bogastvo npr. Jelovice, Notranjske, Kočevskega, Trnovskega gozda, Pohorja itd.

Nekatera naša gozdna območja gozdov imajo tudi funkcijo lova evropskega pomena in možnost ureditve edinstvenega "safarija" za oglede zveri in drugih velikih živali v naravnem okolju - seveda v popolni razmejitvi od območij naselij, rekreacije in kmetijstva!

\section{Turizem}

V turističnem razvoju se Slovenija sooča $z$ močno konkurenco evropskih in zunajevropskih turističnih (in drugih prostočasnih) središč ter regij. Zato moramo razvijati velike, v ponudbi raznovrstne centre, ki imajo zadostne naravne in vse druge prostorske komparativne prednosti. Imajo naj vse potrebne tudi sestavine umetnega, grajenega okolja. So tudi pogoj za uspešno, konkurenčno funkcioniranje okolnih agrarno-turističnih regij, območij eko-turizma ipd. Turistična središča morajo imeti zadostno velikost in s tem ekonomičnost obsega, manjšo odvisnost od naravnih pogojev, dobro dostopnost, naravne privlačnosti itd.

Naši europsko konkurenčni ("evroturistični") centri so:

- Bled z okolico;

- Bohinj $z$ okolico in kot izhodišče v TNP;

- Bovec $z$ gornjim Posočjem in kot izhodišče $\mathrm{v}$ TNP $\mathrm{z}$ območ- jem Kanin - Sella Nevea ter Kobaridom kot izhodiščem $\mathrm{k}$ pomnikom Soške fronte;

- Portorož s Piranom, Lucijo in okolico (turistično regijo okoli Izole in Ankarana);

- Ljubljana z okolico (Kamnikom, Škofjo Loko, Barjem, Polhograjskimi Dolomiti ...);

- Maribor s Pohorjem in drugo okolico;

- Postojna, tudi kot izhodišče za Škocjanske jame, Cerkniško jezero in Rakov Škocjan.

Da bi dosegli evropsko konkurenčno ponudbo tudi za druge turistične regije, je potrebno izgrajevati in programsko dopolnjevati poleg že naštetih predvsem sledeča "regionalna" turistična središča (ki imajo potencialno mednarodni pomen):

- Kranjska Gora z Ratečami, Planico, Martuljkom in Tromejo;

- Rogaška Slatina z okolico;

- Podčetrtek z okolico;

- Čatež z okolico - Brežicami, Mokricami;

- Ptuj $\mathrm{Z}$ okolico (tudi Ptujsko goro);
- Zreče (terme in okolica) z Zreškim Pohorjem;

- Lipica $z$ možnim novim zabaviščnim "evroparkom", avtodromom, nakupovalnim središčem pri Kozini ali Divači (sečišče treh avtocestnih smeri in s tem stičišče treh držav ter lega na turistični smeri zahodna Evropa-Dalmacija).

Smotrno bi bilo razvijati nove turistične centre in regije in sicer:

- zimsko športni in planinski center Notranjski Snežnik (tudi za turistično zaledje kvarnerskega območja),

- intenzivni razvoj turistične regije Obkolpje (med Kostelom, Faro in Osilnico).

Ostala obstoječa turistična središča imajo $v$ mednarodnem merilu le omejeno konkurenčno možnost razvoja in naj bo turistična ponudba predvsem dopol nilna dejavnost na kmetih oziroma prostočasna funkcija mest ter regij. Imajo zlasti regionalni pomen (tudi za sosednje države in slovensko turistično tržišče).

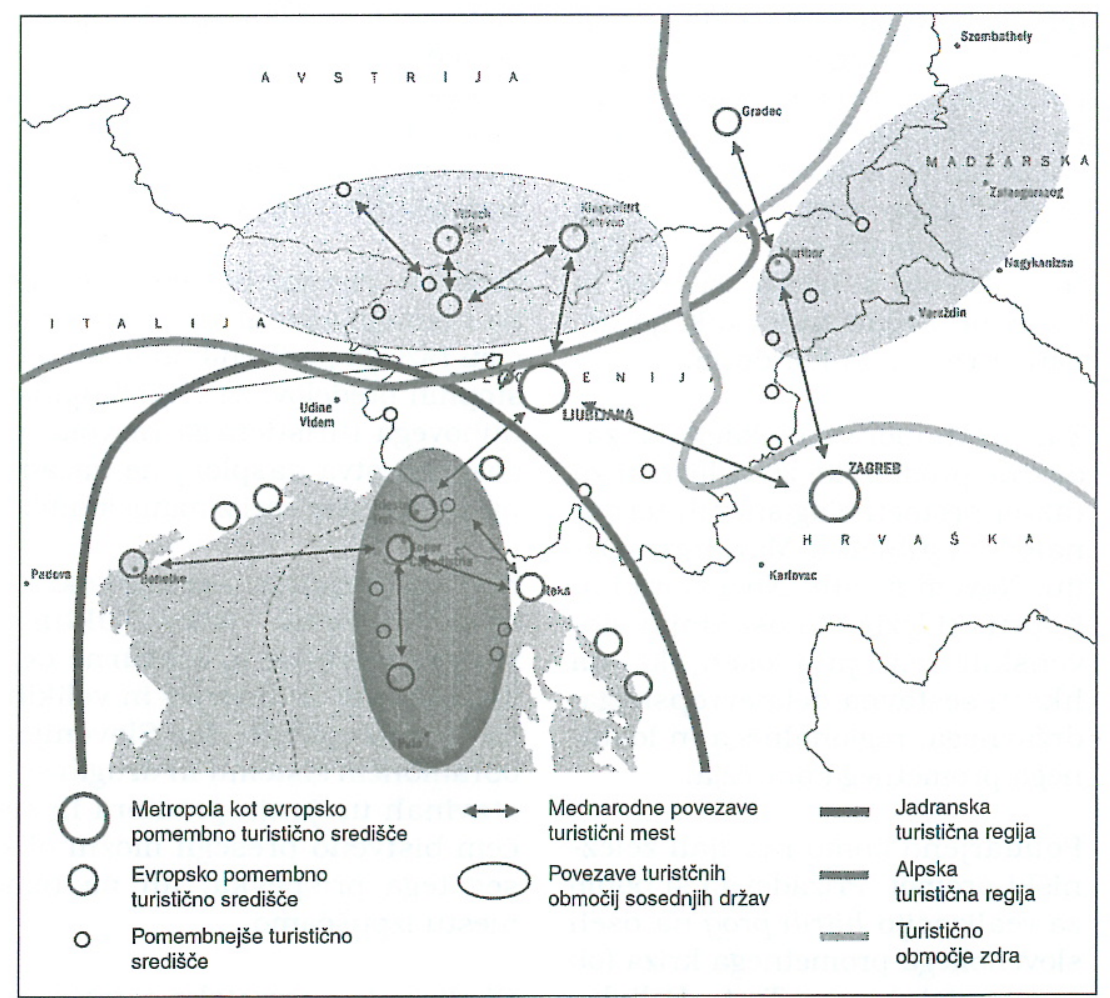

Slika 6: Turistične regije in možno povezovanje sosednjih držav 


\section{Promet}

O razvoju prometnih sistemov $\mathrm{v}$ luči mednarodnega položaja Slovenije je bilo napisanega in narisanega že ogromno. Zato smo se spričo omejenega obsega tega članka odločili, da o tem segmentu posebej ne pišemo in bomo našteli le nekaj načel:

Na slovenski prometni križ, ki ga bodo tvorile avtocestne in hitre železniške povezave, bomo navezovali urbana središča, gospodarske cone, turistične regije ter prek sekundarnih prometnih sistemov periferne regije. Oba transevropska transportna koridorja naj krepita kohezivnost slovenskega prostora in njegovo povezanost $z$ Evropo.

$\mathrm{V}$ prometno izoliranih območjih bomo krepili povezave $z$ osrednjeslovenskim metropolitanskim območjem, kar še zlasti pomeni izgradnjo prometnic $\mathrm{v}$ smereh vzhod-zahod in sever-jug.

Vključenost v transevropske prometne sisteme bo nujno privedla tudi do avtocestnih (in železniških) povezav na smereh Italija Hrvaška in Avstrija - Hrvaška. Na teh oseh, ki so za Slovenijo tranzitne in manj ugodne, bomo krepili naselitvena jedra, nakupovalne in gospodarske cone ter turistični razvoj. Avtocestna povezava med tržaško regijo in Hrvaško prek Reke mora potekati čez Sežano, Divačo in Ilirsko Bistrico in $\mathrm{s}$ tem opravljati tudi funkcijo urbano razvojnega koridorja.

Zagotoviti moramo lokacije in zadostne prostorske zmogljivosti za razvoj prometnologističnih terminalov v Ljubljani, Mariboru, Celju, Novem mestu, Novi Gorici in Kopru, ki ležijo na osrednjih slovenskih razvojnih oseh, ki sta hkrati sestavna dela evropskega, državnega, regionalnega in lokalnega prometnega omrežja.

Poudarjeno bomo razvijali železniški promet. Prizadevali si bomo za realizacijo hitrih prog na oseh slovenskega prometnega križa (ob že nastajajoči progi Trst - Beljak Gradec se pojavljata konkurenčni smeri tudi na oseh Trst - Reka Zagreb - Budimpešta in Dunaj Maribor - Zagreb). Hitra proga Italija - Balkan mora potekati skozi Ljubljano (Trst - Ljubljana Zagreb), hitra proga med Dunajem in Zagrebom pa prek Maribora, Celja in Zidanega Mosta!

Pomorsko orientacijo države bomo uresničevali $\mathrm{z}$ dosledno zahtevo po mednarodno priznanem dostopu do mednarodnih morij, razvojem vseh funkcij plovnega prometa (npr. potniško pristanišče, vojna luka, ribiška baza, ladjedelstvo). Priključili se bomo na ploune rečne poti podonavskih $\mathrm{dr}$ žav. Slednje lahko realiziramo s podaljšanjem hrvaške plovne poti po Dravi do Središča (ob Dravi) ali po Kolpi do Metlike.

Krepili bomo vlogo zračnega prometa in pomena slovenskih letališč v jugovzhodni regiji Evrope, tudi $\mathrm{z}$ dopolnilnimi dejavnostmi čarterskega in cargo prometa, vojaškimi in turističnimi funkcijami. Ni odveč razmislek o novem letališču v Koprščini, ki bi dal Obali novo razvojno vzpodbudo.

Krepili bomo vlogo drugih vrst prometa, kot sta kolesarski in peš promet, ter njihove navezave na evropska omrežja kolesarskih in peš poti. Jačali bomo vlogo javnega prometa in vseh drugih oblik, ki zmanjšujejo obremenitve okolja.

Krepili in razvijali bomo tudi lokalna čezmejna prometna omrežja v cilju razvoja perifernih in težko dostopnih predelov, za vzpodbujanje njihovega turističnega razvoja in gospodarstva nasploh, ne nazadnje za krepitev vezi $z$ manjšinami.

Ker bi z razpravo o energetski in okoljevarstveni infrastrukturi, varstvu naravne in kulturne dediščine, eko-koridorjih in velikih kulturnih "poteh" čez Slovenijo, obrambnem sistemu in drugih sestavinah urejanja prostora in še čem bistveno presegli možni obseg tega prispevka, jih na tem mestu izpuščamo.

Okoljsko in energetsko potratnost prometa moramo zmanjšati $z$ bi- modalnimi ali večmodalnimi transportnimi verigami (vodni železniški promet, železniški - kolesarski promet itd.).

Prof. dr. Andrej Pogačnik, mag. arh., Katedra za prostorsko planiranje, Fakulteta za gradbeništvo in geodezijo, Univerza v Ljubljani

\section{Izbor iz literature}

Evropean Commission: Evropean Spatial Development Perspective / ESDP, Potsdam 1999.

CEMAT: Guiding Principles for Sustainable Spatial Development Policy in Evrope, Dunaj 2000.

ÖROK: Austria within the Framework of Spatial Development Policy in Evrope, Dunaj 1996.

Delovna skupina REGIONALP: Prostorsko planiranje in regionalni razvoj v (vzhodno) alpskem prostoru; Avstrija, Italija, Nemčija, Švica, Liechtenstein 2000.

Delovna skupnost Alpe-Jadran: Skupne smernice za urejanje prostora; MOP - URSPP, Ljubljana 1997.

Evrope 2000+; Regional Planning for the Year 2000, Factsheet, 1995.

Evropean Environment Agency; Evrope's Environment, The Dobriš Assessment, Luxembourg 1995.

Ministarstvo prostornog uredjenja, graditeljstva i stanovanje: Strategija prostornog uredjenja republike Hrvatske, Zagreb 1997.

Ministrstvo za okolje in prostor RS: Analiza prostorskih razvojnih možnosti Slovenije, Ljubljana 2000 (nepubl.).

Ministrstvo za okolje in prostor RS Urad RS za prostorsko planiranje: Politika urejanja prostora - osnutek predloga, Ljubljana 1998 (nepubl.).

Ministrstvo za okolje in prostor RS: Analiza prostorskih razvojnih možnosti Slovenije, Ljubljana 2000 (nepubl.).

Pogačnik, Andrej, in dr.: Variante možnega prostorskega razvoja države Slovenije in njihovo izvrednotenje; Univerza v Ljubljani - Fakulteta za gradbeništvo in geodezijo, Ljubljana 1997 (nepubl.).

Skupne smernice za urejanje prostora; MOP - URSPP, Ljubljana 1997.

Trans Evropean Networks / TINA, 1995, Final report; Luxemburg 1999.

Vision Planet: Strategies for Integrated Spatial Development of the Central Evrope, Danubian and Adriatic Areas, Dunaj 2000. 